\title{
APLIKASI PENJADWALAN MATA PELAJARAN SMA BERBASIS WEB MOBILE DI SMA NEGERI 2 PRINGSEWU
}

\author{
Taufiq $^{1}$, M. Faqih Alfarizi ${ }^{2}$, Sri Ipnuwati ${ }^{3}$ \\ Prodi Sistem Informasi, STMIK Pringsewu Lampung \\ Jl. Wisma Rini No. 09 pringsewu Lampung \\ E-mail :taufiqstmikpsw@gmail.com,faqihalfarizi24@gmail.com,negachie@gmail.com
}

\begin{abstract}
ABSTRAK
Permasalahan dalam mendapatkan jadwal dalam kegiatan belajar mengajar merupakan masalah yang sering terjadi, khususnya di SMA N 2 Pringsewu. Proses untuk mendapatkan jadwal dengan kertas masih memiliki kekurangan yaitu tidak mudahnya penyampaian informasi kepada siswa.Sedangkan siswa yang ingin mengetahui jadwal pelajaran di kelasnya dengan cara menghubungi ke teman sekelasnya melalui telepon atau melihat jadwal yang ditempel di mading tempat siswa belajar, sehingga untuk memudahkan bagian akademik dalam penyusunan jadwal dan penyampaian informasi jadwal ke pengajar serta siswa, maka dibutuhkan sebuah aplikasi penjadwalan berbasis web mobile. Sistem ini memiliki keunggulan dimana dapat diakses oleh pengguna menggunakan web browser yang terdapat di seluruh sistem operasi komputer desktop dan smartphone. Metode pengembangan sistem yang digunakan adalah SDLC (System Development Life Cycle) yang terdiri dari beberapa tahapan, yaitu tahap perencanaan, tahap analisis, tahap desain, tahap implementasi dan tahap pemeliharaan pengembangan sistem. Hasil dari penelitian ini adalah aplikasi penjadwalan mata pelajaran berbasis web mobile yang diharapkan dapat membantu siswa dalam mendapatakan jadwal secara lebih akurat sebagai pedoman atau panduan dalam belajar.
\end{abstract}

Kata Kunci :Sistem Informasi,Penjadwalan,Web Mobile

\section{ABSTRACT}

Problems in obtaining the schedule in learning activities is a problem was often the case, especially in high school $n 2$ pringsewu. The process to obtain the schedule with paper still having a deficiency that is they did not easy it is dissemination of information among students

The best student who wants to find out how timetables in his class by means of contact into her classmates as via the telephone or see with the schedule that posted in mading place students learn to so as to make it easier for academic part in the preparation of the the schedule and was given to disseminating information a schedule to image and a teacher of and student of, it takes an application web based scheduling the operation of mobile.

This system having the same where can be accessed by the user using a web browser that is in the whole system the operation of a computer desktop and smartphone.Method of development a system used is sdlc ( system development life cycle) consisting of some stages, namely the planning stages, the analysis, the design, phase implementation and the maintenance system development.

The result of this research is application scheduling subjects web-based mobile is expected to help students in mendapatakan schedule in a more accurate as guidance or guide in learning.

Key words: an integrated information system for, scheduling, a web mobile 


\section{PENDAHULUAN}

\subsection{Latar Belakang Masalah}

Menurut hasil penelitian yang dilakukan penggunainternet di Indonesia yang berasal dari kalangan anak-anak dan remajamencapai 30 juta. Datatersebut merupakan hasil penelitian berjudul "KeamananPenggunaan Media Digital pada Anakdan Remaja di Indonesia" yang yang dilakukanlembagaPBB untuk anak-anak, UNICEF, bersama para mitra, termasuk Kementerian Komunikasi dan Informatika dan Universitas Harvard, AS.

Studi ini menelusuri aktivitas online dari sampel anak dan remaja yang melibatkan 400 responden berusia 10 sampai 19 tahun di seluruh Indonesia dan mewakili wilayah perkotaan dan pedesaan.Sebanyak 98 persen dari anak dan remaja mengaku tahu tentang internet dan 79,5 persen di antaranya adalah pengguna internet. Maka dari itu sudah tidak efisien lagi membagikan jadwal pelajaran dengan menggunakn kertas karena sekarang rata-rata pelajar menghabiskan waktu dengan telepon pintar mereka hanya untuk internetan(www.kompas.com).

Jadwal mata pelajaran di sekolah merupakan hal yang sangat penting dalam berlangsungnya kegiatan belajar mengajar di sekolah, jadwal ini bertujuan untuk mendukung, memperlancar, dan mempertinggi kualitas pendidikan. Secara umum jadwal mata pelajaran berfungsi untuk aktivitas akademik dalam mempertinggi kualitas mengajar dan kedisiplinan baik guru maupun siswa.

Dengan adanya jadwal mata pelajaran, kegiatan belajar mengajar akan berjalan dengan lancar, baik, dan efisien. Sehingga kegiatan belajar mengajar di sekolah bisa dilaksanakan secara maksimal. Sampai saat ini jadwal pelajaran di beberapa sekolah masih menggunakan kertas sehingga banyak para murid sering kehilangan informasi adanya jadwal pelajaran yang baru yang di buat oleh bagian kurikulum, dari hasil pengamatan yang berdasarkan pengalaman yang dirasakan oleh peneliti bahwa memberikan informasi jadwal pelajaran menggunakan kertas tidaklah efektif. Penelitian yang dilakukan oleh Fajar Kurniawan tahun (2012),Penelitian tersebut menghasilkan sistempenyusunan jadwal pelajaran sekolah dalam bentuk aplikasi web menggunakan bahasa pemprograman PHP serta MYSQL sebagai databasenya. Peneliti juga menggunakan CSS dan Jquery untuk mendukung tampilan dari perangkat lunak ini sehingga menghasilkan tampilan yang interaktif [1].

Penelitian yang dilakukan oleh Rudi Hermawan(2016), Menggunakan Bahasa Pemrograman PHP dan Database MYSQL. Penelitian tersebut menghasilkan sistem penyusunan jadwal pelajaran di Ganesha Operation dalam bentuk aplikasi web dimana pengajar dan siswa dapat melihat laporan jadwal melalui website. Perbedaan penelitian yang akan dilakukan oleh penulis saat ini dengan penelitian sebelumnya adalah, dimana pada penelitian sebelumnya jadwal yang dibuat dalam bentuk website dekstop yang kurang responsif jika menggunakan web dengan browser yang ada di handphone. Pada penelitian yang akan dilakukan oleh penulis akan membuat jadwal pelajaran yang berbasis web mobile yang gunanya lebih responsif jika mengakses melalui handpone atau smartphone [2].

Ada beberapa hal yang sangat dirasakan dari para pelajar mengenai informasi jadwal pelajaran yang didapatkan oleh para pelajar adalah melalui slebaran kertas yang di fotocopy dan bertanya kepada teman-teman. Hal ini dirasakan kurang menunjang kebutuhan karena mereka tidak bisa setiap saat melakukan pengecekan jadwal pelajaran. Untuk memecahkan masalah yang terjadi, maka diperlukan suatu sistem yang dapat menangani permasalahan tersebut, salah satunya yaitu dengan membuat aplikasi penjadwalan mata pelajaran berbabis web mobile yang mempermudah para pelajar agar bisa mendapatkan jadwal tanpa harus bertanya kepada temannya. Cukup menggunakan sebuah handphone para pelajar bisa melihat jadwal pelajaran yang akan di pelajari di sekolahan.

\subsection{Rumusan Masalah}

Berdasarkan latar belakang tersebut penulis merumuskan masalah-masalah sebagai berikut :

1. Bagaimana Merancang Sebuah Aplikasi penjadwalan mata pelajaran berbasis web mobile pada SMAN2 Pringsewu. 
2. Bagaimanakah Mengimplementasikan Aplikasi penjadwalan berbasis web mobile?

\section{LANDASAN TEORI}

\subsection{Penjadwalan}

Menurut Pinedo penjadwalan adalah proses pengambilan keputusan yang berkenaan dengan pengalokasian sumber daya terbatas untuk tugas-tugas dari waktu ke waktu yang memiliki tujuan untuk mengoptimasi dari satu atau lebih tujuan. Sumber daya dan tugas pada sebuah organisasi dapat berupa berbagai macam bentuk. Sumber daya dapat berupa mesin di bengkel, landasan pacu di bandara, kru di lokasi konstruksi, unit pengolahan dalam lingkungan komputasi, dan sebagainya. Tugas dapat berupa operasi-operasi dalam proses produksi, tinggal landas dan pendaratan pada bandara, tahapan-tahapan dalam proyek konstruksi, eksekusi program komputer, dan sebagainya. Setiap tugas mungkin memiliki tingkat prioritas tertentu, kecepatan waktu mulai tertentu dan tanggal jatuh tempo tertentu. Tujuan juga dapat berupa berbagai macam bentuk. Tujuan penjadwalan organisasi yang satu mungkin untuk meminimalkan waktu yang dibutuhkan untuk menyelesaikan suatu tugas, sedang tujuan penjadwalan organisasi yang lain adalah untuk mengurangi jumlah tugas yang selesai setelah tanggal jatuh tempo [3].

\subsection{PHP}

PHP adalah singkatan dari "PHP: Hypertext Preprocessor", yang merupakan sebuah bahasa scripting yang terpasang pada Hypertext Markup Language (HTML). Sebagian besar sintaks mirip dengan bahasa $C$, Java dan Perl, ditambah beberapa fungsi $P H P$ yang spesifik. Tujuan utama penggunaan bahasa ini adalah untuk memungkinkan perancang web menulis halaman web dinamik dengan cepat [4], [5].

\subsection{MySQL}

SQL adalah suatu bahasa komputer yang mengikuti standar American National Standard Institute (ANSI), yaitu sebuah bahasa standar yang digunakan untuk mengakses dan melakukan manipulasi sistem database (Fauzi
2012)[6]. Untuk melakukan administrasi dalam basis data MySQL, dapat menggunakan modul yang sudah termasuk yaitu commandline (perintah: mysql dan mysqladmin). Juga dapat di unduh dari situs MySQL yaitu sebuah modul berbasis grafik (GUI), MySQL Administrator dan MySQL Query Browser. Selain itu terdapat juga sebuah perangkat lunak gratis untuk administrasi basis data MySQL berbasis web yang sangat popular yaitu phpMyAdmin [7][8].

\subsection{Web Mobile}

Web Mobile adalah sebuah teknologi baru yang telah mengakomodasi kebutuhan akan akses internet melalui perangkat mobile (bergerak), jika sebelumnyainternet hanya dapat diakses melalui komputer maka dengan adanya teknologi web mobile, sebuah web akan dapat diakses melalui perangkat bergerak seperti telepon seluler dan PDA/Pocket PC[9][11].

\section{METODE PENELITIAN}

\subsection{Pengumpulan Data}

\section{a. Observasi}

Observasi adalah pengamatan langsung pada suatu obyek yang akan diteliti. Peneliti melakukan pengamtan secara langsung di SMA N 2 Pringsewu untuk memperoleh data secara intensif dan faktual.

\section{b. Interview}

Interview adalah pengamatan langsung dengan cara bertanya secara langsung kepada para pelajar yang berada di SMA N 2 Pringsewu. Peneliti bertanya secara langsung kepada para pelajar yang bersekolah di SMA N 2 Pringsewu.

\section{c. Pustaka}

Yaitu dengan mengumpulkan berbagai sumber-sumber referensi baik berupa buku, artikel dan sumber-sumber lainya sebagai acuan dalam analisis dan perancangan system.

\subsection{Metode Pengembangan Sistem}

Muhammad Muslihudin dan Oktafianto (2016) SDLC (Sytem Develoment Life Cycle, Siklus Hidup Pengembangan Sistem) dalam rekayasa sistem dan rekayasa perangkat lunak 
adalah proses pembuatan dan pemgubahan sistem serta model dan metodelogi yang digunakan untuk mengembangkan sistemsistem tersebut. SDLC terdiri dari beberapa tahap yaitu : perencanaan, analisis, desain, pengkodingan, impelentasi, uji coba dan testing[12].

\subsection{Alur Penelitian}

Alur penelitian ini menjelaskan tentang bagaimana tahapan atau langkah-langkah penelitian di SMA N 2 Pringsewu untuk sebuah aplikasi jadwal mata pelajaran berbasis web mobile yang bertujuannya mempermudah para pelajar untu mendapatkan jadwal mata pelajaran. Berikut ini adalah diagram alur penelitian yang dimulai dari persiapan dalam menentukan tujuan dari penelitian yang akan dilakukan hingga akhirnya didapatkan hasil yang ingin dicapai dalam penelitian ini.

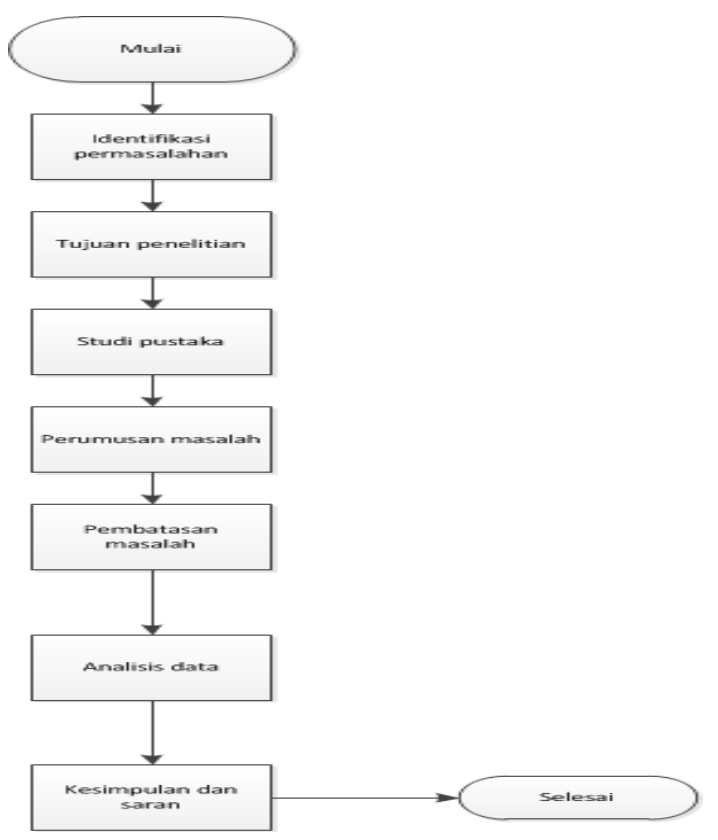

Gambar 1. Flowchart Penelitian

\section{PEMBAHASAN}

\subsection{Perancangan}

Perancangan sistem pada aplikasi penjadwalan mata pelajaran berbasis web mobile bertujuan untuk memberikan gambaran untuk mengidentifikasikomponen yang akan di desain. Tahap desain sistem secara umum dilakukan setelah tahap analisa selesai dilakukan Desain sistem pada aplikasi.

\section{a. Usecase}

Diagram Usecase mendepenelitiankan sebuah interaksi antara satu atau lebih aktor dengan sistem yang akan dibuat. Usecase digunakan untuk mengetahui fungsi apa saja yang ada di dalam sebuah sistem dan siapa saja yang berhak menggunakan fungsi-fungsi tersebut

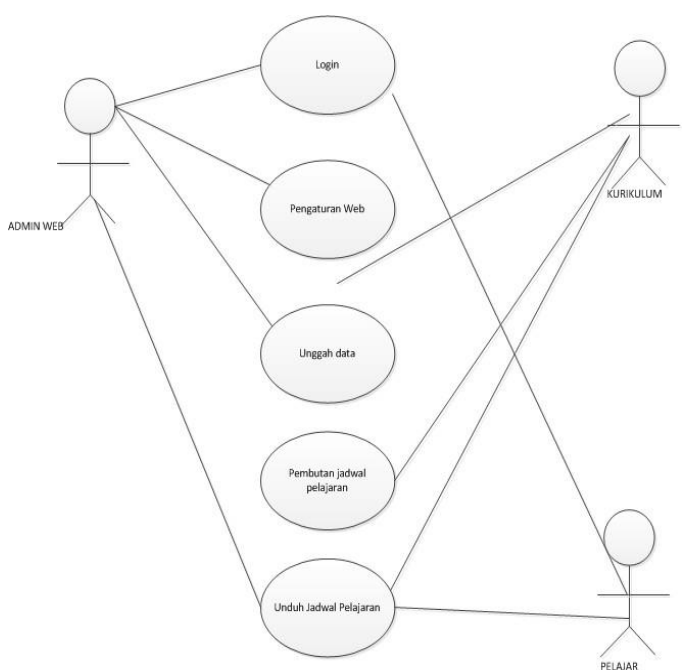

Gambar 2. Diagram Usecase

\section{b. Perancangan ERD}

Entity Relationship Diagram adalah modul yang mendepenelitiankan hubungan antara penyimpanan menggunakan sejumlah notasi dan simbol untuk menggambarkan struktur dan hubungan antar data.

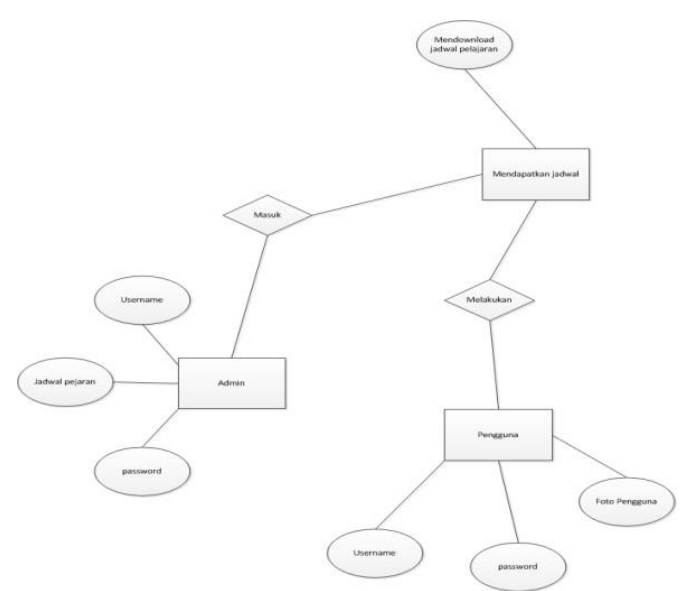

Gambar 3. Diagram ERD 


\subsection{Perancangan Antarmuka}

Perancangan antarmuka merupakan proses pembuatan yang akan digunakan untuk berinteraksi antara pengguna dengan perangkat lunak.

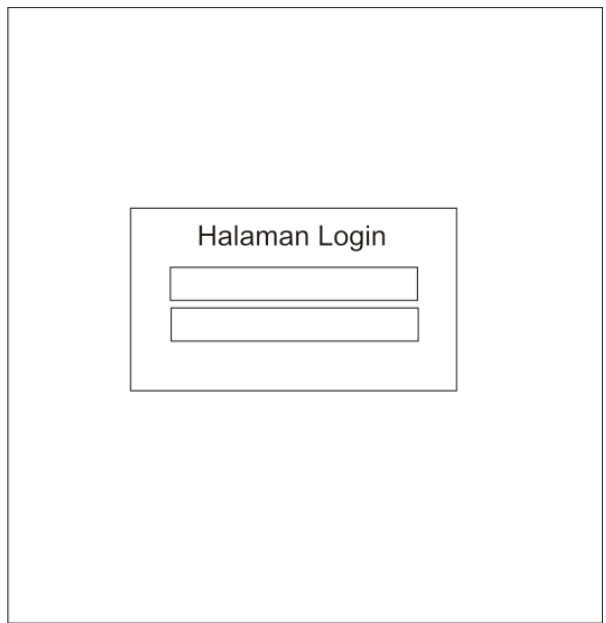

Gambar 4 . Tampilan Login

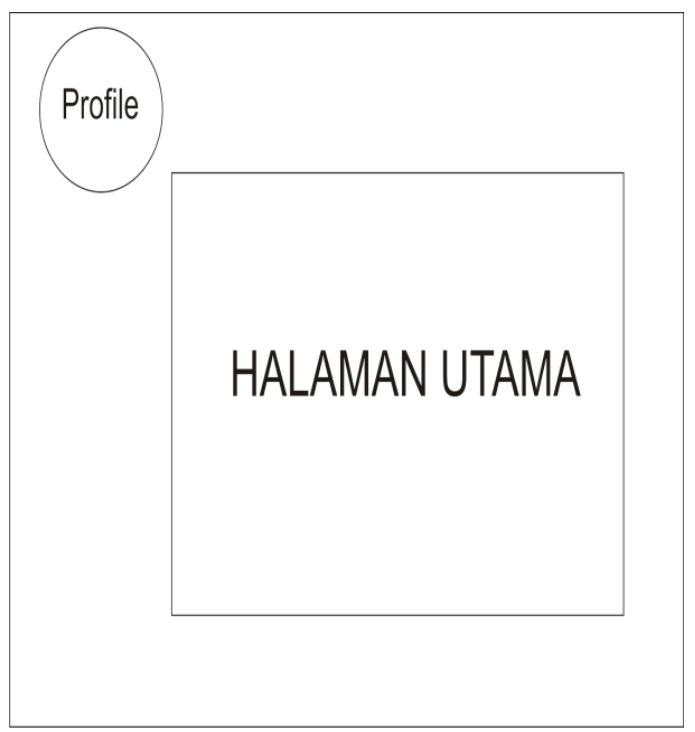

Gambar 5. Tampilan Halaman utama

\subsection{Impelentasi}

Dari Hasil Rancangan yang telah dilakukan, hasil dari aplikasi yang dibangun dapat terlihat seperti gambar dibawah ini :

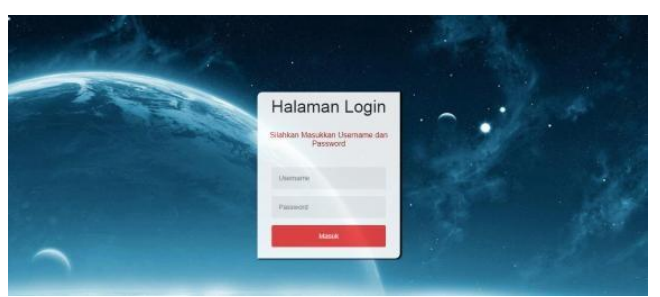

Gambar 6. Halaman Login Admin dan Pengguna

Halaman admin ditampilkan sebagai link dalam halaman home yang bertempat di footer untuk mempermudah administrator dalam maintenance website. Halaman admin mempunyai halaman awal login, untuk masuk ke menu utama user harus melakukan login. Halaman login administrator akan mencocokan username dan password, setelah username dan password sesuai dengan database maka user dapat masuk sebagai admin .

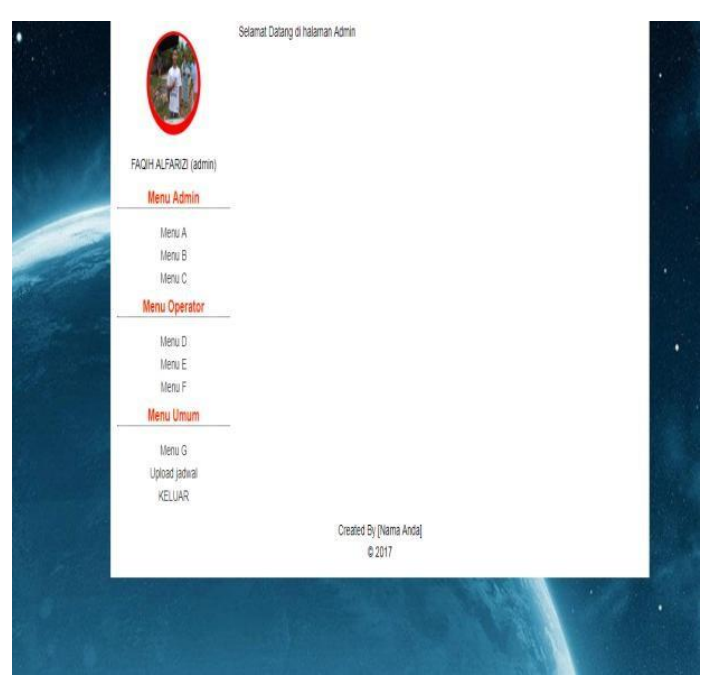

Gambar 7. Halaman Admin 


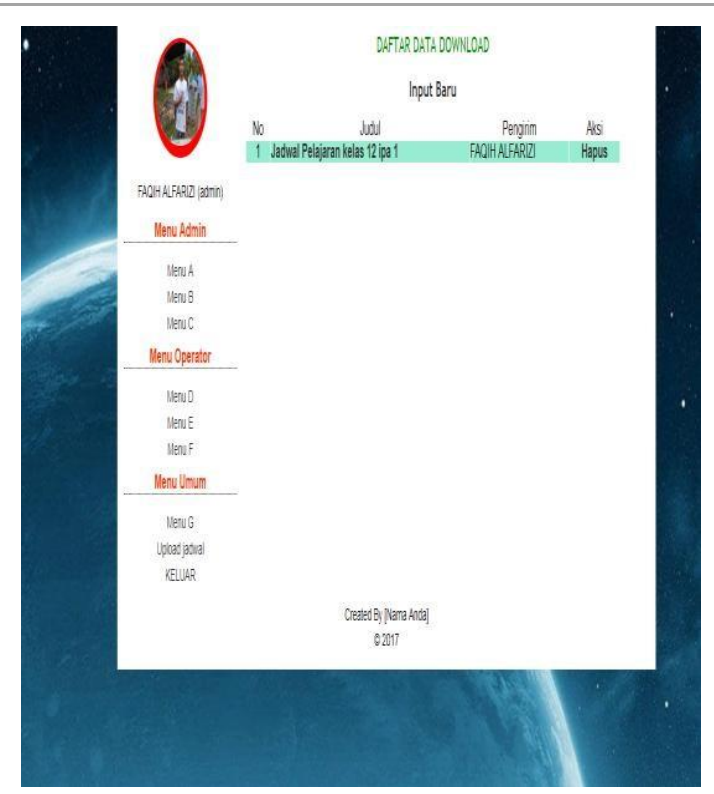

Gambar 8. Halaman Upload Jadwal Mata pelajaran

Halaman pengguna ditujukan untuk para pengguna yang ingin mendapatkan jadwal, pada halaman pengguna ini berisi halaman login pengguna dan halaman untuk mengunduh jadwal pelajaran

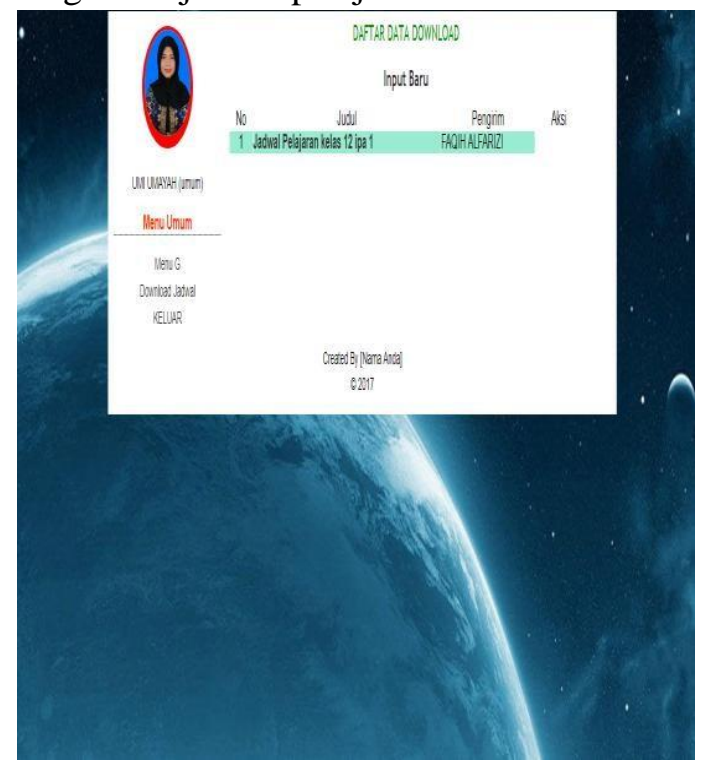

Gambar 9. Halaman Unduh Jadwal Pelajaran

\subsection{Analisis Hasil}

Berdasarkan hasil uji coba fungsi aplikasi pada menu login,user data, mengunduh data, dan logout. Setelah dilakukan pengujian secara fungsional terhadap menu yang ada didalam aplikasi ini, maka didapatkan hasil yang menunjukan bahw aplikasi sesuai dengan rancangan namun ada sedikit kendala di dalam desainnya yang kurang menarik tetapi dalam programnya dapat berjalan dengan baik.berdasarkan uji coba terhadap 15 orang $70 \%$ dari itu banyak yang menyukainya sedangkan

$30 \%$ tidak suka sama sekali.

\section{PENUTUP}

\subsection{Kesimpulan}

Berdasarkan penelitian dan pembahasan yang telah dilakukan dapat diambil kesimpulan sebagai berikut :

1. Dibangunnya aplikasi Penjadwal mata pelajaran dapat membantu dalam memperlancar jalannya belajar dan mengajar serta mempermudah mendapatkan jadwal pelajaran tanpa takut kehilangan.

2. Aplikasi penjadwan mata pelajaran berbasis web mobile dapat mempermudah para pelajar untuk mendapatkan jadwal pelajaran hanya dengan mengakses internet melalui web.

\subsection{Saran}

Berdasarkan kesimpulan diatas, diharapakan untuk penelitian yang akan datang dalam pengembangan aplikasi penjadwalan mata pelajaran berbasis web mobile ini nantinya dapat berjalan di semua sistem operasi.

\section{Daftar Pustaka}

[1] F. Kurniawan, "Sistem Punyusunan Jadwal Pelajaran," Tek. Inform. UNY, pp. 1-6, 2013.

[2] R. Hermawan, A. Hidayat, and V. G. Utomo, "Kata kunci: sistem informasi, penjadwalan, berbasis web," J. Softw. Eng. Sist., vol. 2, no. 1, pp. 31-38, 2016.

[3] S. Mujab, K. I. Satoto, and K. T. Martono, "Perancangan Sistem Informasi Akademik Berbasis Mobile Web Studi Kasus di Program Studi Sistem Komputer Universitas Diponegoro," J. Teknol. dan Sist. 
Komput., vol. 2, no. 1, pp. 1-11, 2014.

[4] K. Fergiawan Listianto, Fauzi, Rita Irviani, "Aplikasi E-Commerce Berbasis Web Mobile Pada Industri Konveksi Seragam Drumband Di Pekon Klaten Gadingrejo Kabupaten Pringsewu," J. TAM ( Technol. Accept. Model ), vol. 8, no. 2, pp. 146-152, 2017.

[5] M. Muslihudin and A. Larasati, "Perancangan sistem aplikasi penerimaan mahasiswa baru di stmik pringsewu menggunakan php dan mysql," J. TAM ( Technol. Accept. Model ), vol. 3, no. 1, pp. 12-23, 2014.

[6] M. M. A. Fauzi, Program Database Visual Basic 6 and SQL Server 2000. Yogyakarta: Andi Offset, 2012.

[7] R. Irviani and R. Oktaviana, "Aplikasi Perpustakaan Pada SMA N1 Kelumbayan Barat Menggunakan Visual Basic," J. TAM ( Technol. Accept. Model ), vol. 8, no. 1, pp. 3445, 2017.

[8] R. Irviani and P. Setiawan, "Aplikasi Berbagi Pesan Berbasis Web Sebagai Media Komunikasi Di STMIK Pringsewu," SEMNASTEKNOMEDIA, vol. 5, no. 1, pp. 13-18, 2017.

[9] S. I. Ikwan, Ahmad, "Perancangan Web Government Pada Kecamatan Natar Lampung Selatan Berbasis Mobile," JTKSI, vol. 1, no. 2, pp. 1-4, 2018.
[10] S. F. Achmad, Fandi, "Rancangan Sistem Informasi Berbasis Web Mobile Potensi Lampung Tengah," JTKSI, vol. 1, no. 1, pp. 1-4, 2018.

[11] M. M. Samsudin, Imam, "Implementasi Web Government Dalam Meningkatkan Potensi Produk Unggulan Desa Berbasis Android," JTKSI, vol. 1, no. 2, pp. 10-16, 2018.

[12] O. Muhammad Muslihudin, Analisi Dan Perancangan Sistem Informasi Menggunakan Model Terstruktur Dan UML. Yogyakarta: Andi Offset, 2016.

Sumber Internet :

A. Panji 2014, Hasil Survei Pemakaian Internet Remaja Indonesia, Diakses 1 januari 2018dari 